\title{
ORGANISATIONAL POLITICS - CAUSES AND EFFECTS ON ORGANISATION AND EMPLOYEES
}

\author{
Sule, Olatunji Eniola ${ }^{\dagger}$--- Amuni, Sarat Iyabo ${ }^{2}$--- Ashiru, Titi Adeshina ${ }^{3}$ - \\ Ariyo, Oladayo Olajide ${ }^{4}$ \\ ${ }^{\prime}$ Business Administration Department, Olabisi Onabanjo University, Ago-Iwoye, Ogun State, Nigeria \\ ${ }^{2}$ Library \& Information Management Department, Tai Solarin University Of Education, Ijebu-Ode, Ogun State, Nigeria \\ ${ }^{3}$ Business Administration Department, Olabisi Onabanjo University, Ago-Iwoye, Ogun State, Nigeria \\ ${ }^{4}$ Business Administration Department, Olabisi Onabanjo University, Ago-Iwoye, Ogun State, Nigeria
}

\begin{abstract}
This work was just to look at the causes and the effects of politics within organisation. It started with the reasons for groups within organisations, causes and possible effects of organisational politics on the organisation and the employees. Finally, the work made it clear that employees need to relate which may give room for politicking but moderation and utmost supervision should be the guarding principle.
\end{abstract}

Keywords: Politics, Organisational, Organisation, Group, Coalition, Employee, Politician.

Received: 7 September 2015/ Revised: 7 October 2015/ Accepted: 12 October 2015/ Published: 17 October 2015

\section{Contribution/ Originality:}

This study contributes to the existing body of knowledge and literature by exposing that politics exist within organisation. The study went further to give adequate meaning to politics within organisation and finally documents mainly the likely causes and effects of excess organisational politics on employees and organisation.

\section{INTRODUCTION}

Every organisation depends largely on its workforce and this workforce relates with other factors of production- land, capital and entrepreneur, as well as relating among themselves. The relationship among the workforce leads to friendship which invariably leads to group and/or association. It must be noted, therefore, that in every organisation, there are always two 
important groups and/or associations. First, we have the known and identified group called the formal group like the trade union/association. These groups are very popular in virtually all organisations which is a collective of individual workers within the same organisation coming together with known aims and objectives, and most importantly, can be related to as a group through selected representatives within the organisation. The other group which most scholars referred to as informal group is not usually easy to identify within the organisation. They are collection of the liked-mind personnel/workers within organisation usually on similar cadre and responsibility with no identified leader(s) but very powerful in deeds and actions.

The presence of both formal and informal group within organisation necessitated politics and solidarity within organisation. Note, an organisation is a subset of a community, as such most attitudes and actions going on in the society are always a replica of it in the organsation(s) within such community. It is a sub-set because workforce of an organisation is a representation of almost every household of a community. The reasoning of two people will be seriously influenced by their background, experience, knowledge and particularly the peer group. Hence, there will be organisational politics among the workforce. This is because of different way we perceive issues. For instance, half full cup of water and/or half empty cup of water.

The term organisational politics is used to describe negotiations and settlements within organisations made necessary by the existence of contrasting interests and the differing perceptions of various organsational members; or better still, could be described as "the pursuit if individual agendas and self-interest in an organisation without regard to their effect on the organisation's efforts to achieve its goals". Political activities lead to compromises, toleration and a stability of relationship which enables the organisation to survive.

Organisational politics typically involved the building of coalitions around issues, persuasions and advocacy and skillful development of resources and power. Control over information is the key tool in the process. Coalitions arise in consequence of bargaining among various interest groups and dominant coalition will emerge. Organisational politics affect which issue assumes prominence within the organisation and how they are discussed and interpreted. The manner in which a problem is diagnosed may be determined primarily by the self-interest of the influential individuals and coalitions. Hence, organisational politics influences how decisions are taken as well as decisions themselves. Certain rules, procedures and interpersonal relationship might develop outside the official management system.

A company's political power system can affect its organisation structure, even to the extent that the latter becomes unsuitable as a means for realizing the structure that are deemed acceptable and, once implemented, the organisation design most favoured by the dominant political group that might perpetuate itself indefinitely.

Therefore, organisational politics represents attempt to influence others using discretionary behaviours to promote personal objectives. It is the exercise of power to get one's own way, including the acquisition of more power, often at the expense of others. Behaviours are 
discretionary if they are neither formally prescribed nor prohibited by the organisation (Drory and Romm, 1990).

\section{CAUSES OF ORGANISATIONAL POLITICS WITHIN ORGANISATIONS}

Based on the general presumption that all animals are political animals, we tend to carry out politics to have our way or an edge over and above others due to many reasons. Some of these reasons include:

1. Organisational politics come into play when the organisation faces severe resources constraints, so that individuals and departments are compelled to fight very hard, for instance, their departmental budget allocations.

2. Politics come into play within organisation when the internal and external environments of the organisation are fast changing.

3. It is very important for every organisation to have a clear and distinct objective to shape all the activities within the organisation but whenever this is lacking people tends to take undue advantage of this situation and as a result, organisational politics may result from this.

4. When key managers have fundamentally different opinions about the basic purpose of the organisation, the managers individually work towards different purpose and these attitudes may result in organisational politics.

5. In situations when there is little or no accountability in the organisation, everybody wants to out-smart the other.

6. Finally, when there is inadequate management control in an organisation, then what you have is individual interest which gives rise to organisational politics.

\section{EFFECTS AND IMPLICATIONS OF ORGANISATIONAL POLITICS ON ORGANISATIONS}

Whenever there is organisational politics going on within the organisation, departments are always encouraged one way or the other to seek sections dependent on them, regardless of whether these inter-relationships benefit the firm as a whole.

Again, sectional goals might be inconsistent across the organisation and not shared by all individuals and departments within the organisation. Like it was mentioned earlier that individuals form groups within the organisation, they tried to belong to their like-minds individuals becoming section of sections and as such the section's goal will be a sectional goals to jettison the organisational goal.

Managers may also become obsessed with ideological struggle, conflict and gaining the upper hand, at the expense of getting on with their work.

Bad decision might result from the internal political bargaining process as well as deteriorating the interpersonal relationships may occur in the organisation. 
Decision processes can become disorganized and disorderly, just as inaccurate information might be deliberately circulated. Politics lowers the output of an individual and eventually affects the productivity of the organization. Common observation says that individuals who play politics at the workplace pay less attention to their work. For instance, what do you say of a staff that had suffered partial stroke and claimed he cannot carry-out the work with which he was employed but could attend meetings, workshops and go on courses within and outside the organisation, just because he is a union member. Such human being will be more interested in leg pulling and back biting. They will spend most of their times criticizing their fellow workers. As a result of politics at the workplace, employees cannot achieve targets within the stipulated time frame. As a result, work gets delayed in such an organization.

Politics leads to a negative environment at the workplace. When the environment is not conducive the relationships amongst individuals get spoilt. An individual playing politics at the organization is disliked by all because is seen as lazy and arrogant. Some employee's attitude change because of politics in the organisation. Even the serious employees lose interest in work and attend office just for the sake of it. Internal politics may not allow employees to give their full concentration and devotion to work. No matter how much hard work an employee puts in, it might go unnoticed in a politically driven organization.

A non performer can be the apple of his boss's eye simply due to politics, thus demotivating the performers. Discussions are essential at the workplace to extract the best out of employees. Evaluating the pros and cons of an idea always helps in the long run. Employees playing politics always look for an opportunity to tarnish the image of the fellow workers. Employees feel demotivated when they are not rewarded suitably or someone who has not worked hard gets the benefits due to mere politics.

It is rightly said that problems evaporate if discussed. Individuals will find it difficult to confide in any of their fellow workers due to the fear of secrets getting leaked. As s result, politics increases the stress level of the employees. Individuals are expected to discuss and share idea since they are not machines who can work continuously for 8-9 hours without talking to others. Therefore, it is important to have friends at the workplace who help you when needed but individuals fail to trust each other. Such organisation could be called or described as "Animal Farm".

Employees indulged in politic manipulate information and it is never passed on in its desired form. Superiors can never get a true picture of happenings in the organization. Then, a wrong person walks away with the credit in an organization where employees are indulged in politics.

\section{CONCLUSION}

Politics in organsation should be avoided seriously due to its ugly effect on the organisation and its employees. Some of the effects include decrease in overall productivity, lack of concentration by the employees, spoils the ambience and changes the attitude of employees. 
Others are demotivating employees, stress increase on the part of employees and spreading of wrong information by employees to gain the attention of the superior.

It must be noted that it is excess of everything that is bad. Every organisation need to allow their employees to relate together since we all agreed that they are not machines who can survive in isolation. But, moderation and effective monitoring of the activities of the so-called "politicians" within the organisations should be the watch-word.

\section{REFERENCES}

Drory, A. and T. Romm, 1990. The definition of organisational politics: A review. Human Relations, 43(11): $1133-1154$

\section{BIBLIOGRAPHY}

Frost, P.J. and D.C. Hayes, 1983. An exploration in two cultures of a model of political behaviour in organisations, in organisational influence processes. Allen R. W. and Porter L.W., Eds., Glenview, IL: Scott, Foresman. pp: 369-392.

Kasumar, K.M. and G.R. Ferris, 1993. Politics at work: Sharpening the focus of political behaviour in organisations. Business Horizon, 36(4): 70-74. 